Archive for

Organic Chemistry

Arkivoc 2020, part viii, 20-32

\title{
A new synthesis of some $2,4^{\prime}$-biindolyls
}

\author{
Glenn C. Condie, Naresh Kumar, and David StC. Black* \\ School of Chemistry, UNSW Sydney, Sydney, NSW 2052, Australia
}

Email:d.black@unsw.edu.au

Received 08-04-2020

Accepted $10-02-2020$

Published on line $10-12-2020$

\section{Abstract}

New 2,4'-biindolyls have been synthesized using new methodology enabled by the regioselective reactivity of methyl 5,7-dimethoxyindole-2-carboxylate, which undergoes a modified Vilsmeier-Haack reaction at C4 with indolin-2-one in the presence of phosphoryl chloride. Selective formylation and acylation with oxalyl chloride of the resulting 2,4'-biindolyl were achieved at $\mathrm{C4}$, and the resulting glyoxyloyl chloride was converted to related glyoxylic amides. Removal of the ester substituent at $\mathrm{C2}$ of the 2,4'-biindolyl produced a more reactive biindolyl, which underwent sequential mono-formylation at C3' and then at C3. The selective reactivity of the biindolyls is attributed to conjugation between the two indole moieties, and evidence for the degree of conjugation was observed via ${ }^{1} \mathrm{H}$ NMR spectroscopy.

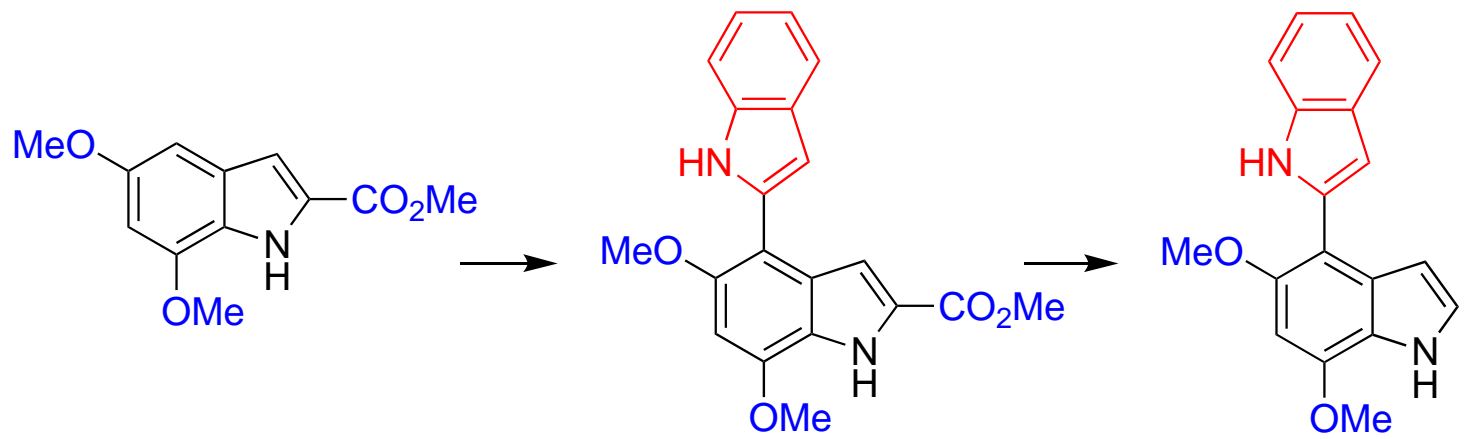

Keywords: Indoles, biindolyls, Vilsmeier-Haack reaction, 2-indolinones 


\section{Introduction}

The 2,4'-biindolyls have received considerable attention, predominantly in connection with tryptophan tryptophylquinone (TTQ) 1 (Figure 1). TTQ is a novel o-quinone cofactor found in bacterial methylamine dehydrogenases (MADH) and aromatic amine dehydrogenase (AADH) and is tightly associated in the enzyme matrix through a peptide linkage. TTQ is derived from two tryptophan residues at the enzyme active site and is the redox centre of MADH and $A A D H$, catalysing the oxidation of primary amines to the corresponding aldehydes and ammonia. ${ }^{1-3}$

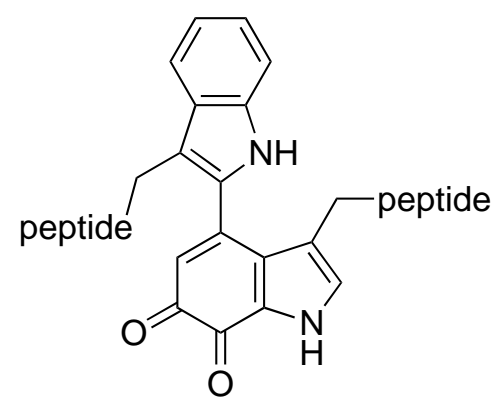

TTQ

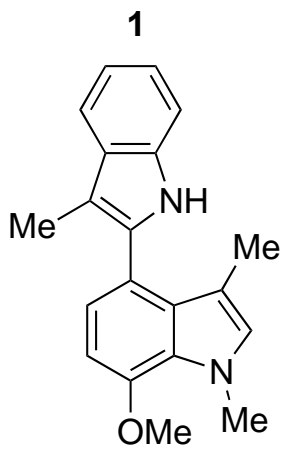

4<smiles>O=C1NC(=O)C2=C1c1cccc3[nH]cc2c13</smiles>

arcyriacyanin A

2

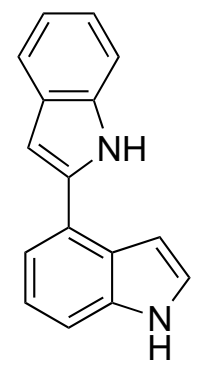

3

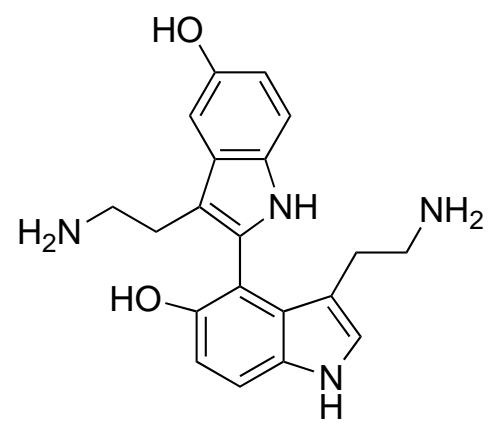

6

Figure 1. Some naturally-occurring and synthetic 2,4'-biindolyls.

The 2,4'-biindolyl structure is also present in natural products such as the blue-green pigment arcyriacyanin A 2 (Figure 1) isolated from the slime mould Arcyria obvelata (= A. nutans, Myxomycetes). ${ }^{4-6}$ Steglich and co-workers reported three strategies for the synthesis of arcyriacyanin A 2, including one wherein the preparation of the parent 2,4'-biindolyl $\mathbf{3}$ (Figure 1) was achieved via Stille coupling of a stannylindole with 1-tosyl-4-bromoindole. ${ }^{6}$ Murase and co-workers ${ }^{5}$ also prepared the parent 2,4'-biindolyl 3, via a palladium catalysed cross-coupling reaction of an indolylborate and a 4-iodoindole. Both methods require $\mathrm{N}$-protection and deprotection during the preparation of the 2,4'-biindolyl. In both groups the work was then directed towards the coupling of the Grignard reagent of 2,4'-biindolyl 3 with $N$-protected dibromomaleimide to give arcyriacyanin A 2. Itoh and co-workers synthesized 2,4'-biindolyl 4 (Figure 1) via a Fischer indolization of the related 4-propionylindole. ${ }^{7}$ Biindolyl 4 was then converted into the indolequinone derivative 5 (Figure 1), which was studied as a model for the organic cofactor TTQ of bacterial amine dehydrogenases. ${ }^{1}$

In the earlier literature 2,4'-biindolyls were reported by Prota and co-workers in the context of melanin and eumelanin structures and biosynthesis. 5,7-Dihydroxyindole was found to undergo dimerization to form the related 2,4'-biindolyls via photo-oxidation, autoxidation, and enzymic oxidation. ${ }^{8-10} 5,5^{\prime}-$ Dihydroxy-2,4'- 
bitryptaminyl 6 (Figure 1) was observed as a minor constituent of four dimeric products formed during the controlled potential electrochemical oxidation of millimolar concentrations of 5-hydroxytryptamine (5-HT) in aqueous solutions at $\mathrm{pH} \mathrm{2,{ } ^ { 1 1 }}$ while a trimer was isolated from the electrochemical oxidation of 5,6dihydroxytryptamine (5,6-DHT). ${ }^{12}$ More recently Prota and co-workers examined the oxidative degradation of these 2,4'-biindolyls to form substituted pyrroles, as part of their study of the mechanism of pigment breakdown of mammalian skin, hair, and eyes. ${ }^{13}$

The selective electrophilic substitution of methyl 5,7-dimethoxyindole-2-carboxylate $7^{14,15}$ was used to prepare a 2,4'-diindolyl compound and the reactivity of this compound towards electrophilic substitution was investigated. Attempts were also made to bridge the C3 and C3' positions of the 2,4'-biindolyl compound.

\section{Results and Discussion}

\section{Synthesis of Methyl 5,7-dimethoxy-4-(indol-2'-yl)indole-2-carboxylate 9}

Numerous imines have been prepared by the modified Vilsmeier-Haack reaction, in which dimethylformamide was replaced by secondary amides such as anilides, pyrrolidinones, piperidinone, and 4,4-dimethyl-2oxazolidinone. ${ }^{16,17}$ Bergman and Eklund have also reported the preparation of 2,3'-biindolyls by combination of 1-methylindole and 1-methylindolin-2-one in the presence of phosphoryl chloride. ${ }^{18} 4,6$-Dimethoxyindoles with substituents at either or both of $\mathrm{C} 2$ and $\mathrm{C} 3$ have been reacted with indolin-2-ones in the presence of either phosphoryl chloride or trifluoromethanesulfonic anhydride (triflic anhydride) to give biindolyls, the regiochemistry being determined by the most reactive position available. ${ }^{19,20}$ Generally the indole and indolin2-one were refluxed together in chloroform with phosphoryl chloride. A certain level of reactivity is necessary, as dimethyl 4,6-dimethoxyindole-2,3-dicarboxylate (with two deactivating ester groups) failed to react with indolin-2-one 8 in the presence of phosphoryl chloride: however, when triflic anhydride was employed the desired $2,7^{\prime}$-biindolyl was obtained in $70 \%$ yield. ${ }^{19}$

We have previously reported on the general reactivity of methyl 5,7-dimethoxyindole-2-carboxylate 7 and disclosed that this indole undergoes selective electrophilic substitution at C4. ${ }^{14,15}$ Thus a $2,4^{\prime}$-biindolyl would be expected to form from the condensation of indole $\mathbf{7}$ and indolin-2-one 8 . A solution of the indole $\mathbf{7}$ and indolin-2-one $\mathbf{8}$ in chloroform was heated under reflux with two equivalents of phosphoryl chloride for days without reaction. The approach using triflic anhydride was also attempted but gave no reaction after several days at room temperature. However, under forcing conditions, indole $\mathbf{7}$ and indolin-2-one 8 in neat phosphoryl chloride at $60{ }^{\circ} \mathrm{C}$ for 2.5 hours gave biindolyl 9 as fine yellow needles in quantitative yield (Scheme 1).

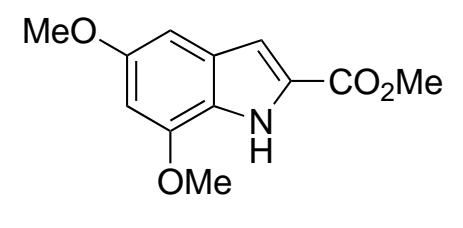

7
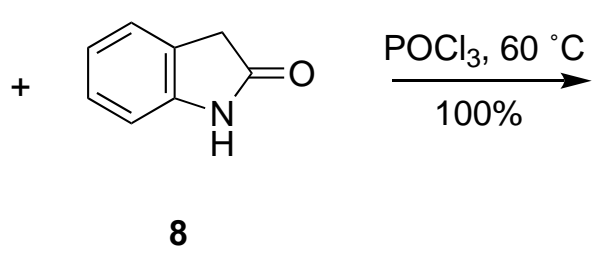

8

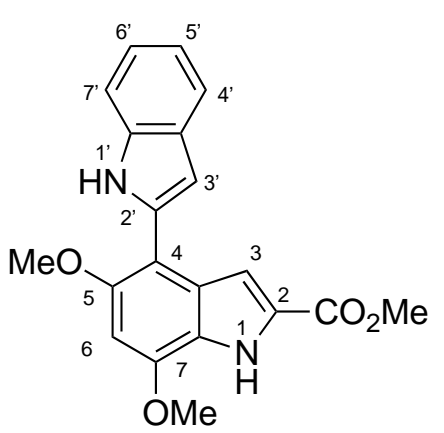

9

Scheme 1. Synthesis of 2,4'-biindolyl 9. 
The ${ }^{1} \mathrm{H}$ NMR spectrum $\left(\mathrm{CDCl}_{3}\right)$ of biindolyl 9 included a doublet at $7.63 \mathrm{ppm}$, corresponding to $\mathrm{H} 3$, and showing the expected coupling with the $\mathrm{NH}$ proton of the dimethoxyindole nucleus, indicating that substitution had occurred at $\mathrm{C} 4$. The singlet resonance at $6.63 \mathrm{ppm}$, corresponding to $\mathrm{H} 6$, also confirmed substitution at $\mathrm{C} 4$. It is also interesting to note that of the two indole $\mathrm{NH}$ signals, the broader resonance at $9.43 \mathrm{ppm}$ corresponds to the $\mathrm{NH}$ of the less substituted indole nucleus and is shifted downfield due to hydrogen bonding to the nearby methoxy group. Another consequence of the hydrogen bonding is broadening and a decreased height of the methoxy singlet at $3.92 \mathrm{ppm}$. In comparison with the preparation of 2,4'biindolyls $\mathbf{3}$ and $\mathbf{4}$ described above, the preparation of biindolyl $\mathbf{9}$ involved a one-pot procedure and did not require protection of the indole nitrogen.

\section{Electrophilic substitution of methyl 5,7-dimethoxy-4-(indol-2'-yl)indole-2-carboxylate 9}

A consideration of the reactivity of methyl 5,7-dimethoxyindole-2-carboxylate 7 shows that C4 is more reactive than $\mathrm{C} 3$ towards electrophiles. ${ }^{14,15}$ This can be accounted for by the activation of $\mathrm{C} 4$ by the methoxy groups and the deactivation of $\mathrm{C} 3$ by the ester group. In comparison, biindolyl 9 also possesses two competing reactive sites, C3 located on the 5,7-dimethoxyindole nucleus and C3' located on the less substituted indole nucleus. The dimethoxyindole nucleus is electron rich due to the presence of the methoxy groups, however the $\mathrm{C} 3$ is deactivated by the ester at C2. On the other hand, $\mathrm{C} 33^{\prime}$ of the less substituted indole nucleus is also activated by the methoxy groups and the nitrogen atom of the dimethoxyindole nucleus at $\mathrm{C2}^{\prime}$ and also deactivated by the ester. Formylation of compound 9 was achieved using mild conditions to give only the $3^{\prime}-$ aldehyde $\mathbf{1 0}$ in quantitative yield after careful workup (Scheme 2). Presumably there is also a steric effect supporting this selectivity.

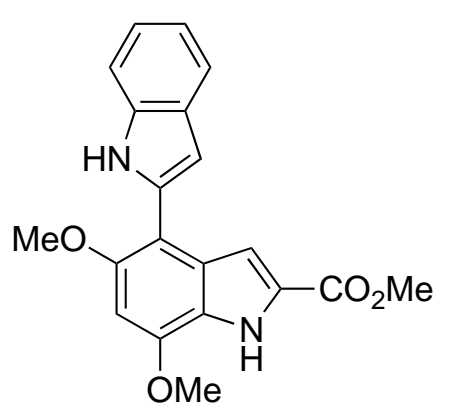

9

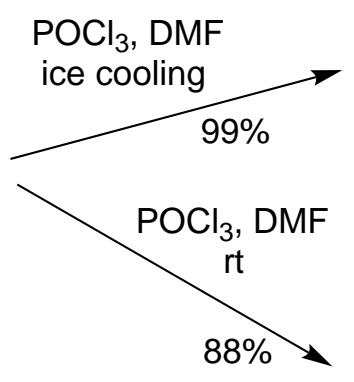

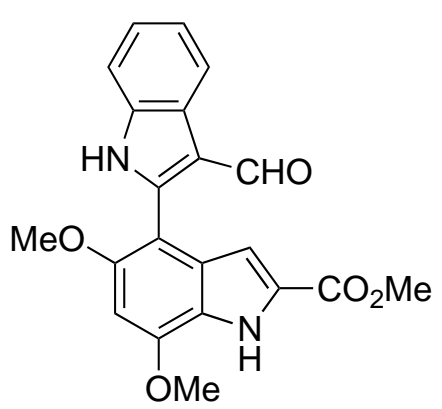

10<smiles>COc1cc(OC)c2[nH]c(C(=O)O)cc2c1-c1[nH]c2ccccc2c1C=O</smiles>

11

Scheme 2. Formylation of 2,4'-biindolyl 9.

The ${ }^{1} \mathrm{H}$ NMR spectrum $\left(\mathrm{CDCl}_{3}\right)$ of 3 '-aldehyde 10 includes an aldehyde resonance at 9.87 ppm along with two indole $\mathrm{NH}$ resonances. In addition, a doublet at $7.10 \mathrm{ppm}$ is assigned to $\mathrm{H} 3$, coupled to the dimethoxyindole $\mathrm{NH}$. A comparison of their NMR spectra shows that the 3'-aldehyde 10 shows weaker 
hydrogen bonding between the less substituted indole $\mathrm{NH}$ and the nearby methoxy group than does the biindolyl 9. This indicates that the two indole nuclei of 3'-aldehyde $\mathbf{1 0}$ are twisted out of plane with respect to each other, thus decreasing conjugation between the two indoles: consequently the formyl group at C3' would have less of a deactivating influence on the 5,7-dimethoxyindole nucleus of biindolyl 10. During the workup process, after basification, if the mixture was allowed to warm to room temperature, the formylated product 10 was observed to dissolve and upon acidification the hydrolysed free acid product $\mathbf{1 1}$ was isolated in $\mathbf{8 8 \%}$ yield (Scheme 2). Attempted diformylation of biindolyl 9 either directly or via the formylation of 3'-aldehyde 10 failed, even with the use of phosphoryl chloride as solvent at $60{ }^{\circ} \mathrm{C}$, while extended reaction times using these forcing conditions only resulted in decomposition. The biindolyl 9 was converted to the glyoxylic amides 13 and 14 , via the glyoxyloyl chloride 12 , which resulted from reaction with oxalyl chloride (Scheme 3).

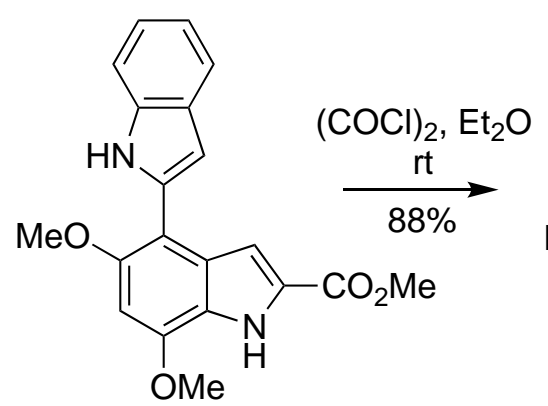

9

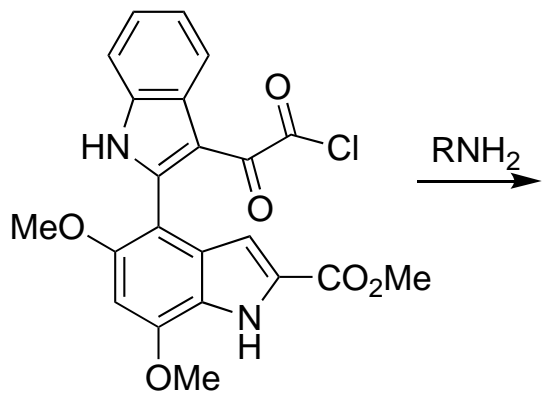

12

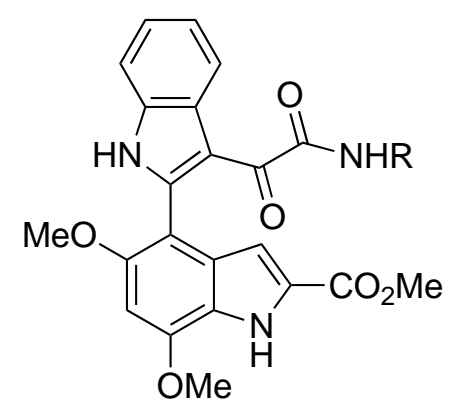

$13 \mathrm{R}=\mathrm{H} \quad 100 \%$

$14 \mathrm{R}=3,5(\mathrm{MeO})_{2} \mathrm{C}_{6} \mathrm{H}_{3} \quad 97 \%$

Scheme 3. Synthesis of glyoxylic chloride 12 and glyoxylic amides 13, 14.

Substitution of the biindolyl 9 by oxalyl chloride at C3 was not observed, neither was cyclization of the 3'indolylglyoxyloyl chloride $\mathbf{1 2}$ on to the C3 position of the dimethoxyindole ring.

\section{Preparation of 5,7-dimethoxy-4-(indol-2'-yl)indole 16}

It was of interest to prepare the less-substituted 5,7-dimethoxy-4-(indol-2'-yl)indole 16 so as to increase reactivity at $\mathrm{C} 3$. Thus biindolyl 9 was refluxed in aqueous ethanolic potassium hydroxide to give the carboxylic acid $\mathbf{1 5}$ in quantitative yield. A mixture of the carboxylic acid $\mathbf{1 5}$ and copper powder in quinoline was then heated at reflux to give the 5,7-dimethoxy-4-(indol-2'-yl)indole 16 in 70\% yield (Scheme 4).

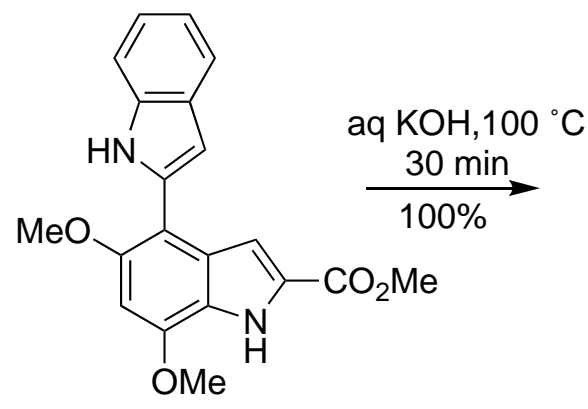

9

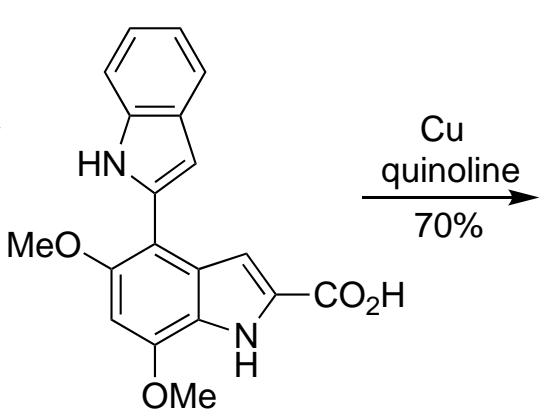

15

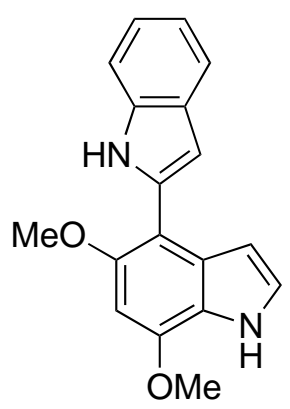

16

Scheme 4. Synthesis of 2,4'-biindolyl 16. 
A comparison of the ${ }^{1} \mathrm{H}$ NMR spectra $\left(\mathrm{CDCl}_{3}\right)$ of biindolyl 9 and biindolyl 16 reveals that the dimethoxyindole $\mathrm{NH}$ resonance of biindolyl $\mathbf{1 6}$ is shifted upfield with respect to that of the dimethoxyindole $\mathrm{NH}$ of biindolyl 9 due to the absence of hydrogen bonding with the ester at $\mathrm{C} 2$. There is no significant change in the chemical shifts of the less substituted indole $\mathrm{NH}$ protons in the two biindolyl compounds. Also, the hydrogen bonding interaction between the less substituted indole $\mathrm{NH}$ and the $\mathrm{C} 5$ methoxy group of the 5,7dimethoxyindole nucleus is observed in the NMR spectra of both biindolyls 9 and 16, where the C5 methoxy group resonance is approximately $60 \%$ of the height of the $\mathrm{C} 7$ methoxy group resonance. This indicates that the two indole rings are co-planar and conjugated, thus activating the less substituted indole nucleus towards electrophiles.

\section{Formylation of 5,7-Dimethoxy-4-(indol-2'-yl)indole 16}

The Vilsmeier formylation of biindolyl 16 proceeded quickly using mild conditions to give the 3'-aldehyde 17 as a yellow powder in $91 \%$ yield (Scheme 5). No other product was observed. This result confirms that the biindolyl 16 is more reactive than biindolyl 9, because of the absence of the ester group. Moreover, C3' located on the less substituted indole nucleus is more reactive than C3 located on the 5,7-dimethoxyindole nucleus.

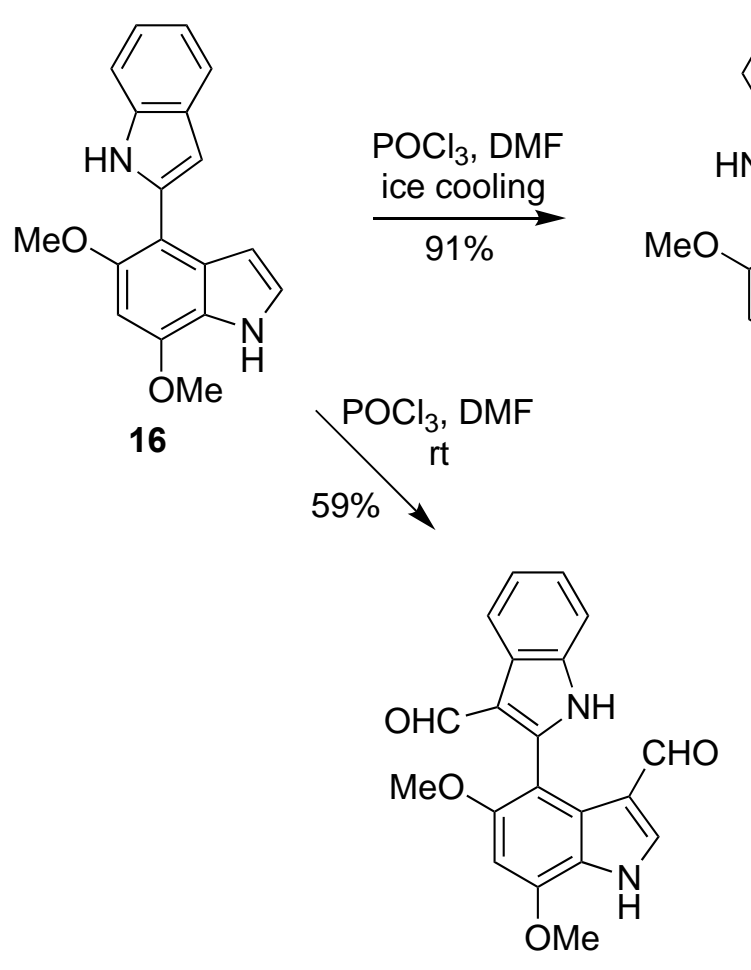

18

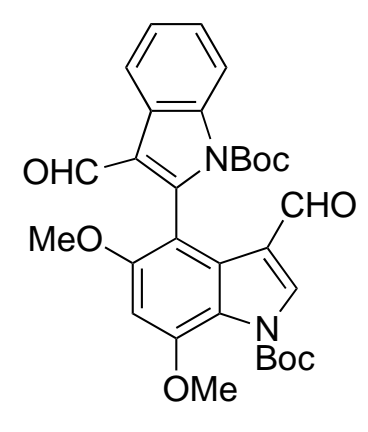

19

Scheme 5. Formylation of 2,4'-biindolyl 16.

The 3'-aldehyde 17 was found to decompose in chloroform over a short period of time to produce intractable tars. However, a ${ }^{1} \mathrm{H}$ NMR spectrum in acid-free $\mathrm{CDCl}_{3}$ showed an aldehyde signal at $9.94 \mathrm{ppm}$. The dimethoxyindole $\mathrm{NH}$ resonance was observed at $8.40 \mathrm{ppm}$, unchanged from that of the biindolyl 16 from which it was derived. The less substituted indole $\mathrm{NH}$ resonance was observed at 8.80 , significantly upfield from that of biindolyl 16, suggesting that there is less interaction between the $\mathrm{NH}$ and the $\mathrm{C} 5$ methoxy group, and therefore less conjugation between the two non-coplanar indole rings. The observation of two methoxy 
signals of equal height is consistent with this situation. Examination of the ${ }^{1} \mathrm{H}$ NMR spectrum (DMSO- $\left.d_{6}\right)$ of $3^{1}-$ aldehyde 17 revealed two multiplets, coupled to each other, corresponding to $\mathrm{H} 2$ and $\mathrm{H} 3$, and consistent with formylation at C3' rather than C3.

The biindolyl 16 could be diformylated under relatively mild conditions to give the 3,3'-dialdehyde 18 as an orange powder in $59 \%$ yield. This compound was also found to decompose quickly in chloroform. The ${ }^{1} \mathrm{H} N \mathrm{NR}$ spectrum in DMSO- $d_{6}$ displays two aldehyde resonances and two indole $\mathrm{NH}$ resonances, while $\mathrm{H} 2$ appears as a doublet at $8.03 \mathrm{ppm}$, showing coupling to the dimethoxyindole NH. Because of its instability, the 3,3'dialdehyde 18 was fully characterized as its stabilized $N, N^{\prime}$-diBoc derivative 19 (Scheme 5). Treatment of the 2,7'-biindolyl 20 with phosphoryl chloride and dimethylformamide has been reported to undergo formylation at C3' to give the indolopyrroloquinoline $\mathbf{2 2}$ in 40\% yield presumably via the C3'-aldehyde 21 (Scheme 6). ${ }^{20}$

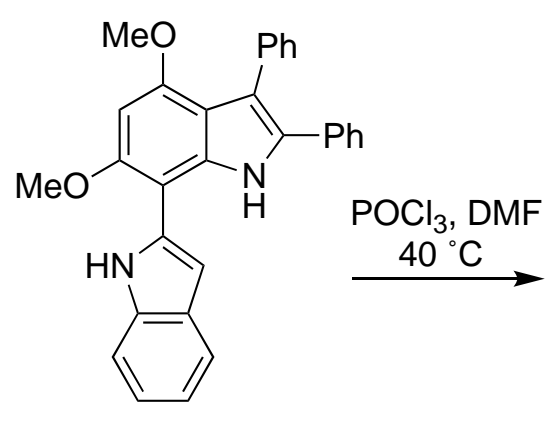

20

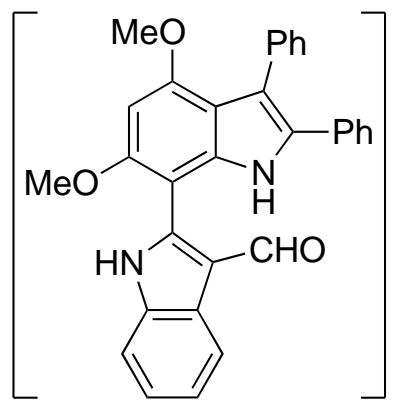

21

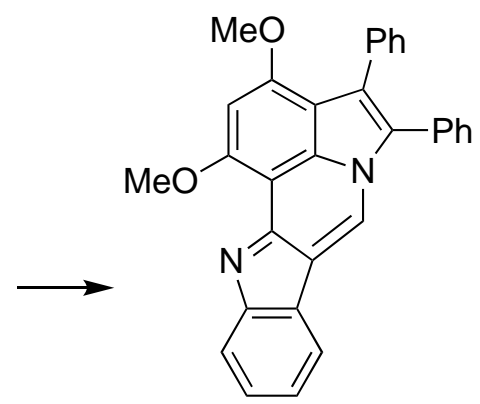

22

Scheme 6. Formation of indolopyrroloquinoline 22.

Attempts to bridge C3 and C3' of biindolyl 16 in order to achieve structures related to arcyriacyanin were unsuccessful. Sequential treatment of biindolyl 16 with methyl magnesium iodide and 3,4dibromomaleimide $^{21}$ left the biindolyl 16 unchanged. The reaction failure could be partly due to the interference from the oxygen atoms of the methoxy groups, which could complex with methyl magnesium iodide. However, attempts to react biindolyl 16 with 3,4-dibromomaleimide, via a Heck reaction were also unsuccessful. Treatment of biindolyl 16 with dimethyl acetylene dicarboxylate ${ }^{18}$ at $205{ }^{\circ} \mathrm{C}$ gave a complex mixture of products and more selective reaction could not be achieved.

\section{Conclusions}

In conclusion, the interesting 2,4'-biindolyl system 9 has been synthesized from methyl 5,7-dimethoxyindole2-carboxylate 7 and was found to undergo regioselective reaction at C3'. The presence of an activating 5,7dimethoxyindole substituent at C2 induced reactivity at the C3' position of the less substituted indole of biindolyl 9, while on the other hand, the presence of the ester at C2 deactivated the C3 position of the dimethoxyindole of biindolyl 9. The degree of coplanarity of the two indole rings is presumably a controlling factor in the stepwise formylation of 2,4'-biindolyl 16. 


\section{Experimental Section}

General. ${ }^{1} \mathrm{H}$ and ${ }^{13} \mathrm{C}$ NMR spectra were recorded on a Bruker AC300F $\left({ }^{1} \mathrm{H}: 300 \mathrm{MHz},{ }^{13} \mathrm{C}: 75.5 \mathrm{MHz}\right)$ or a Bruker AM500 spectrometer. The chemical shifts $(\delta)$ and coupling constants $(J)$ are expressed in ppm and hertz respectively. Carbon attribution $\mathrm{C}, \mathrm{CH}, \mathrm{CH}_{2}$ and $\mathrm{CH}_{3}$ were determined by ${ }^{13} \mathrm{C}$, DEPT and $\mathrm{HMQC}$ experiments. Infrared (IR) spectra were recorded on a Mattson Genesis Series FTIR spectrometer using potassium bromide disks. Ultraviolet and visible (UV/Vis) spectra were recorded in tetrahydrofuran using a Carey 100 spectrometer. Mass spectra were recorded on a VG Quattro MS (EI) or a Finnigan MAT (MALDI). High resolution mass spectrometry (HRMS) was carried out at the Research School of Chemistry, Australian National University. Melting points were measured using a Mel-Temp melting point apparatus. Microanalyses were performed at the Campbell Microanalytical Laboratory, University of Otago, New Zealand. Column chromatography was carried out using Merck 230-400 mesh silica gel or Merck 70-230 mesh silica gel, whilst preparative TLC was performed using Merck 60GF 254 silica gel.

Methyl 4-(indol-2'-yl)-5,7-dimethoxyindole-2-carboxylate (9). A mixture of methyl 5,7-dimethoxyindole-2carboxylate 7 (4.00 g, $17.0 \mathrm{mmol})$ and 2-oxindole $8(2.26 \mathrm{~g}, 17.0 \mathrm{mmol})$ in phosphoryl chloride $(20 \mathrm{~mL}) \mathrm{was}$ stirred in an oil bath at $60{ }^{\circ} \mathrm{C}$ for $2.5 \mathrm{~h}$. After cooling, the mixture was poured onto crushed ice and basified to high $\mathrm{pH}$ with $5 \mathrm{M}$ sodium hydroxide solution. After further stirring for $10 \mathrm{~min}$ with cooling, the resulting precipitate was filtered, washed with water, and dried to give the title compound $(5.96 \mathrm{~g}, 100 \%)$ as a yellow powder, mp 256-258 ${ }^{\circ} \mathrm{C}$ (amyl alcohol); $R_{f}=0.6\left(1 \% \mathrm{MeOH} / \mathrm{CH}_{2} \mathrm{Cl}_{2}\right) . \mathrm{IR}\left(v_{\max }, \mathrm{cm}^{-1}\right): 3445,3329,1704,1589$, 1436, 1316, 1247, 1208s, 1102, 983, 740. UV/Vis $\left(\lambda_{\max }, \mathrm{nm}, \varepsilon, \mathrm{cm}^{-1} \mathrm{M}^{-1}\right): 247(30,000), 276(14,100), 291$ (20,100), 310 (19,700), 361 (12,600). ${ }^{1} \mathrm{H}$ NMR (300 MHz, CDCl $): \delta_{H} 3.92,3.96,4.03$ (each 3H, s, OMe), 6.63 $(1 \mathrm{H}, \mathrm{s}, \mathrm{H6}), 6.97\left(1 \mathrm{H}, \mathrm{br} \mathrm{s}, \mathrm{H} 3^{\prime}\right), 7.12$ and 7.19 (each $1 \mathrm{H}, \mathrm{t}, J \mathrm{~J} .9 \mathrm{~Hz}, \mathrm{H} 5^{\prime}$ and $\left.\mathrm{H} 6^{\prime}\right), 7.43\left(1 \mathrm{H}, \mathrm{d}, J \mathrm{~J} 7.9 \mathrm{~Hz}, \mathrm{H} 4^{\prime}\right), 7.63$ $(1 \mathrm{H}, \mathrm{d}, J 2.3 \mathrm{~Hz}, \mathrm{H} 3), 7.68\left(1 \mathrm{H}, \mathrm{d}, J 7.9 \mathrm{~Hz}, \mathrm{H} 7^{\prime}\right), 9.07(1 \mathrm{H}, \mathrm{br}, \mathrm{NH}), 9.43\left(1 \mathrm{H}, \mathrm{br} \mathrm{s}, \mathrm{NH}^{\prime}\right) .{ }^{13} \mathrm{C} \mathrm{NMR}\left(75 \mathrm{MHz}, \mathrm{d}_{6^{-}}\right.$ DMSO): $\delta_{c}$ 52.0, 56.2 and 57.8 (OMe), 95.6 (C6), 101.5, 108.6, 111.6, 119.1, 119.8 and 120.9 (aryl CH), 105.8, 124.7, 127.1, 128.5, 128.6, 134.1, 136.5, 147.2 and 151.9 (aryl C), 161.7 (들 $\mathrm{Me}) . \mathrm{MS}(+\mathrm{El}, \mathrm{m} / \mathrm{z}, \%): 352$ (3), $351(\mathrm{M}+1,21), 350$ (M, 100), 349 (21), 335 (13), 318 (35), 303 (47), 275 (20). Anal. calcd for $\mathrm{C}_{20} \mathrm{H}_{18} \mathrm{~N}_{2} \mathrm{O}_{4}: \mathrm{C}_{\text {, }}$ $68.56 ; \mathrm{H}, 5.18 ; \mathrm{N}, 8.00$. Found: $\mathrm{C}, 68.47 ; \mathrm{H}, 5.23 ; \mathrm{N}, 8.08 \%$.

Methyl 4-(3'-formylindol-2'-yl)-5,7-dimethoxyindole-2-carboxylate (10). Dimethylformamide (1.0 mL) was cooled in an iced water bath and treated with phosphoryl chloride $(0.11 \mathrm{~mL}, 1.2 \mathrm{mmol})$ and the mixture stirred for $15 \mathrm{~min}$. This solution was then added dropwise, over $8 \mathrm{~min}$, to a similarly cooled and stirred solution of the biindolyl-2-carboxylate $9(0.25 \mathrm{~g}, 0.714 \mathrm{mmol})$ in dimethylformamide $(2.0 \mathrm{~mL})$. The resulting solution was stirred for $50 \mathrm{~min}$ at ambient temperature before it was poured onto crushed ice and basified to high pH with $5 \mathrm{M}$ sodium hydroxide solution. After stirring for $10 \mathrm{~min}$ further with cooling, the mixture was extracted with dichloromethane and the organic extract washed twice with water, dried $\left(\mathrm{MgSO}_{4}\right)$, and the solvent evaporated in vacuo to give the title compound $(0.267 \mathrm{~g}, 99 \%)$ as an orange powder, $\mathrm{mp} 256-258{ }^{\circ} \mathrm{C}\left(\mathrm{CHCl}_{3} / \mathrm{light}\right.$ petroleum); $R_{f}=0.2\left(1 \% \mathrm{MeOH} / \mathrm{CH}_{2} \mathrm{Cl}_{2}\right) . \mathrm{IR}\left(v_{\max }, \mathrm{cm}^{-1}\right): 3265,1708,1632,1585,1457,1326,1259,1218$. UV/Vis $\left(\lambda_{\max }, \mathrm{nm}, \varepsilon, \mathrm{cm}^{-1} \mathrm{M}^{-1}\right): 243(40,000), 295(25,000), 349(11,000) .{ }^{1} \mathrm{H} \mathrm{NMR}\left(300 \mathrm{MHz}, \mathrm{CDCl}_{3}\right): \delta_{\mathrm{H}} 3.91$, 3.84 and 4.07 (each $3 \mathrm{H}, \mathrm{s}, \mathrm{OMe}), 6.63(1 \mathrm{H}, \mathrm{s}, \mathrm{H} 6), 7.10(1 \mathrm{H}, \mathrm{d}, J 2.3 \mathrm{~Hz}, \mathrm{H} 3), 7.30-7.35$ (2H, m, H5' and H6'), 7.43 and $8.43\left(2 \mathrm{H}, \mathrm{m}, \mathrm{H} 4^{\prime}\right.$ and $\left.\mathrm{H}^{\prime}\right), 8.90$ and 9.11 (each $1 \mathrm{H}, \mathrm{br}, \mathrm{NH}$ and $\left.\mathrm{NH}^{\prime}\right), 9.87(1 \mathrm{H}, \mathrm{s}, \mathrm{CHO}) .{ }^{13} \mathrm{C} \mathrm{NMR}(75 \mathrm{MHz}$, $\mathrm{CDCl}_{3}$ ): $\delta_{\mathrm{C}} 52.5,56.3$ and 58.2 (OMe), 94.4 (C6), 108.1, 111.3, 122.6, 123.3 and 124.4 (aryl CH), 103.0, 115.7, 124.1, 126.2, 129.1, 129.6, 136.4, 145.3, 148.9 and 154.0 (aryl C), 162.2 ( CO $\left._{2} \mathrm{Me}\right), 187.3$ (CHO). MS (+El, m/z, \%): 379 (M+1, 13), 378 (M, 57), 348 (19), 347 (100), 319 (17), 315 (67), 303 (25), 289 (15), 275 (15), 216 (16), 
203 (26), 137 (15), 130 (17), 109 (19). Anal. calcd for $\mathrm{C}_{21} \mathrm{H}_{18} \mathrm{~N}_{2} \mathrm{O}_{5}$ : C, 66.66; H, 4.79; N, 7.40. Found: C, 66.49; H, 4.70; N, 7.39\%.

4-(3'-Formylindol-2'-yl)-5,7-dimethoxyindole-2-carboxylic acid (11). Dimethylformamide (2.0 mL) was cooled in an iced water bath and treated with phosphoryl chloride $(0.1 \mathrm{~mL}, 1.0 \mathrm{mmol})$ and the mixture stirred for 15 min. This solution was then added dropwise, over $5 \mathrm{~min}$, to a similarly cooled and stirred solution of the biindolyl-2-carboxylate $9(0.25 \mathrm{~g}, 0.714 \mathrm{mmol})$ in dimethylformamide $(2.0 \mathrm{~mL})$. The resulting solution was stirred overnight at ambient temperature before being poured onto crushed ice and basified to high $\mathrm{pH}$ with $5 \mathrm{M}$ sodium hydroxide solution. After stirring for $30 \mathrm{~min}$ at ambient temperature, the solution was extracted with dichloromethane $(30 \mathrm{~mL}$ ) and the organic layer kept aside (see below). The aqueous layer was acidified to low $\mathrm{pH}$ with conc $\mathrm{HCl}$ and the resulting precipitate was filtered, washed with water, and dried to give the title compound $(0.23 \mathrm{~g}, 88 \%)$ as a fawn coloured powder, $\mathrm{mp} 238-244{ }^{\circ} \mathrm{C}$. IR $\left(\mathrm{v}_{\max }, \mathrm{cm}^{-1}\right): 3486,3466,3326$, $1679,1628,1591,1457,1368,1326,1254,1215$. UV/Vis $\left(\lambda_{\max }, \mathrm{nm}, \varepsilon, \mathrm{cm}^{-1} \mathrm{M}^{-1}\right): 241(41,800), 276(18,700), 295$ $(24,100), 346$ (11,700). ${ }^{1} \mathrm{H}$ NMR (300 MHz, $d_{6}$-DMSO): $\delta_{H} 3.81$ and 4.03 (each $\left.3 \mathrm{H}, \mathrm{s}, \mathrm{OMe}\right), 6.75$ and 6.85 (each $1 \mathrm{H}, \mathrm{s}, \mathrm{H} 3$ and $\mathrm{H6}$ ), 7.18-7.26 (2H, m, H5' and H6'), 7.47 and 8.15 (each $1 \mathrm{H}, \mathrm{d}, J 8.3 \mathrm{~Hz}, \mathrm{H} 4^{\prime}$ and $\left.\mathrm{H} 7^{\prime}\right), 9.64(1 \mathrm{H}, \mathrm{s}$, $\mathrm{CHO}$ ), 11.86 and 12.07 (each $1 \mathrm{H}, \mathrm{br} s, \mathrm{NH}) .{ }^{13} \mathrm{C} \mathrm{NMR}\left(75 \mathrm{MHz}, d_{6}\right.$-DMSO): $\delta_{c} 56.3$ and 57.6 (OMe), 94.4 (C6), 106.9, 112.2, 121.0, 122.3 and 123.4 (aryl CH), 101.7, 114.3, 123.8, 125.6, 128.9, 130.7, 136.8, 145.6, 149.0 and 153.3 (aryl C), $162.5\left(\mathrm{CO}_{2} \mathrm{H}\right), 186.1$ (CHO). MS (MALDI, m/z, \%): 387 (M+Na, 87), 364 (M, 100). Anal. calcd for $\mathrm{C}_{20} \mathrm{H}_{16} \mathrm{~N}_{2} \mathrm{O}_{5} .0 .25 \mathrm{H}_{2} \mathrm{O}: \mathrm{C}, 65.12 ; \mathrm{H}, 4.51 ; \mathrm{N}, 7.59$. Found: $\mathrm{C}, 65.20 ; \mathrm{H}, 4.56 ; \mathrm{N}, 7.48 \%$.

Methyl 4-[3-(chlorooxoacetyl)indol-2'-yl]-5,7-dimethoxyindole-2-carboxylate (12). Oxalyl chloride (0.2 mL, 2 $\mathrm{mmol}$ ) was added to a stirred suspension of the biindolyl-2-carboxylate $9(0.25 \mathrm{~g}, 0.714 \mathrm{mmol})$ in anhydrous ether $(10.0 \mathrm{~mL})$ and stirred overnight, under nitrogen, at room temperature. The resulting precipitate was filtered through a frit, washed with ether, and dried to give the title compound $(0.278 \mathrm{~g}, 88 \%)$ as an orange powder, $\mathrm{mp} 297-301{ }^{\circ} \mathrm{C}$ (dec.). IR $\left(v_{\max }, \mathrm{cm}^{-1}\right)$ : 3387, 3312, 1759, 1721, 1638, 1584, 1451, 1324, 1248,1222 1206. UV/Vis $\left(\lambda_{\max }, \mathrm{nm}, \varepsilon, \mathrm{cm}^{-1} \mathrm{M}^{-1}\right): 242(30,200), 277(16,200, \mathrm{sh}), 342(8,400), 298(19,700) .{ }^{1} \mathrm{H} N M R(300$ $\mathrm{MHz}, d_{6}$-DMSO): $\delta_{H} 3.73,3.77$ and 4.01 (each $\left.3 \mathrm{H}, \mathrm{s}, \mathrm{OMe}\right), 6.66(1 \mathrm{H}, \mathrm{d}, J 1.9 \mathrm{~Hz}, \mathrm{H} 3), 6.75(1 \mathrm{H}, \mathrm{s}, \mathrm{H} 6), 7.24(2 \mathrm{H}$, $\mathrm{m}, \mathrm{H} 5^{\prime}$ and $\mathrm{H}^{\prime}$ ), 7.47 and 8.11 (each $1 \mathrm{H}, \mathrm{m}, \mathrm{H} 4^{\prime}$ and $\mathrm{H} 7^{\prime}$ ), 11.93 and 12.24 (each $\left.1 \mathrm{H}, \mathrm{br} \mathrm{s}, \mathrm{NH}\right) .{ }^{13} \mathrm{C} \mathrm{NMR}(75$ $\mathrm{MHz}, d_{6}$-DMSO): $\delta$ c 52.0, 56.2, and 57.0 (OMe), 94.1 (C6), 107.7, 112.3, 120.9, 122.4, 123.3 (aryl CH), 102.8,

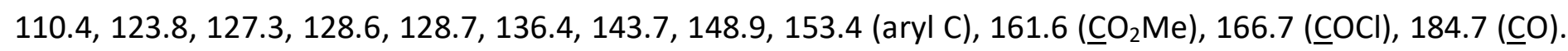
MS could not be obtained. Anal. calcd for $\mathrm{C}_{22} \mathrm{H}_{17} \mathrm{ClN}_{2} \mathrm{O}_{6} .0 .25 \mathrm{H}_{2} \mathrm{O}: \mathrm{C}, 59.33 ; \mathrm{H}, 3.96 ; \mathrm{N}, 6.29$. Found: $\mathrm{C}, 59.29$; H, 4.01; N, 6.33\%.

Methyl 4-[3-(oxamoyl)indol-2'-yl]-5,7-dimethoxyindole-2-carboxylate (13). Oxalyl chloride $(0.07 \mathrm{~mL}, 0.8$ $\mathrm{mmol}$ ) was added to a stirred suspension of the biindolyl-2-carboxylate 9 (50 $\mathrm{mg}, 0.14 \mathrm{mmol}$ ) in anhydrous ether $(10.0 \mathrm{~mL})$ and stirring was continued at room temperature, under nitrogen, for $80 \mathrm{~min}$. The mixture was then cooled in a salt-ice slurry and aqueous ammonia $(2.5 \mathrm{M}, 6.0 \mathrm{~mL})$ was added dropwise over $5 \mathrm{~min}$. The mixture was then heated for $15 \mathrm{~min}$ while the ether was allowed to evaporate and the resulting precipitate was filtered, washed with water, and dried to give the title compound (60 $\mathrm{mg}, 100 \%$ ) as a yellow powder, $\mathrm{mp}$ 299-302 ${ }^{\circ} \mathrm{C} . R_{f}=0.1\left(2.5 \% \mathrm{MeOH} / \mathrm{CH}_{2} \mathrm{Cl}_{2}\right)$. IR $\left(v_{\max }, \mathrm{cm}^{-1}\right): 3451,3351,3252,3179,1717,1682,1625,1592$, $1531,1456,1434,1402,1327,1266,1222,744$. UV/Vis $\left(\lambda_{\max }, \mathrm{nm}, \varepsilon, \mathrm{cm}^{-1} \mathrm{M}^{-1}\right): 243(35,000), 277(18,000), 283$ (20,000), 299 (24,000), 346 (10,000). ${ }^{1} \mathrm{H}$ NMR (300 MHz, $d_{6}$-DMSO): $\delta_{H} 3.72,3.77$ and 4.00 (each 3H, s, OMe), $6.73\left(2 \mathrm{H}, \mathrm{br} \mathrm{s}, \mathrm{H} 3\right.$ and $\mathrm{H6}$ ), $7.19\left(2 \mathrm{H}, \mathrm{m}, \mathrm{H} 5^{\prime}\right.$ and $\mathrm{H6}$ '), 7.07 and 7.53 (each $1 \mathrm{H}$, br s, CONH ${ }_{2}$ ), 7.43 and 8.03 (each $1 \mathrm{H}, \mathrm{d}, J 5.6 \mathrm{~Hz}, \mathrm{H} 4^{\prime}$ and $\mathrm{H} 7^{\prime}$ ), 11.85 and 12.02 (each $1 \mathrm{H}, \mathrm{br} \mathrm{s}, \mathrm{NH}$ and $\mathrm{NH}^{\prime}$ ); signals at 7.07, 7.53, 11.85 and 12.02 ppm exchanged with $\mathrm{D}_{2} \mathrm{O} .{ }^{13} \mathrm{C}$ NMR (75 MHz, $d_{6}$-DMSO): $\delta_{c}$ 52.0, 56.2, 57.2 (OMe), 94.4 (C6), 108.1, 112.0, 120.8, 121.9, 122.8 (aryl CH), 104.4, 110.7, 123.9, 127.5, 128.4, 128.5, 136.3, 142.5, 148.4, 152.9 (aryl C), 161.7 $\left(\mathrm{CO}_{2} \mathrm{Me}\right), 168.4\left(\mathrm{CONH}_{2}\right), 187.7$ (CO). MS (+EI, m/z, \%): 422 (1), $421(\mathrm{M}, 4), 378(9), 377$ (36), 333 (27), 319 
(31), 318 (100), 303 (69), 287 (29), 275 (16), 274 (17), 273 (17), 260 (41), 259 (38), 246 (18), 245 (20), 244 (16), 232 (22), 231 (59), 217 (19), 216 (40), 215 (25), 203 (75). Anal. calcd for $\mathrm{C}_{22} \mathrm{H}_{19} \mathrm{~N}_{3} \mathrm{O}_{6}$ : C, 62.70; H, 4.54; N, 9.97. Found: $\mathrm{C}, 62.70 ; \mathrm{H}, 4.56 ; \mathrm{N}, 9.70 \%$.

Methyl 4-[3-(3",5"-dimethoxyphenyloxamoyl)indol-2'-yl]-5,7-dimethoxyindole-2-carboxylate (14). Oxalyl chloride $(0.10 \mathrm{~mL}, 1.1 \mathrm{mmol})$ was added to a stirred suspension of the biindolyl-2-carboxylate 9 (50 $\mathrm{mg}, 0.14$ $\mathrm{mmol})$ in anhydrous ether $(10.0 \mathrm{~mL})$ and stirring was continued at room temperature, under nitrogen, for $2 \mathrm{~h}$. A hot solution of 3,5-dimethoxyaniline $(44 \mathrm{mg}, 0.29 \mathrm{mmol})$ in water $(5.0 \mathrm{~mL})$ was then added and the open flask heated for $15 \mathrm{~min}$ while the ether was allowed to evaporate. The resulting precipitate was filtered through a frit, washed with water, and dried to give the title compound $(0.08 \mathrm{~g}, 97 \%)$ as a pale orange powder, $\operatorname{mp} 253-255^{\circ} \mathrm{C}$. IR $\left(v_{\max }, \mathrm{cm}^{-1}\right)$ : 3500, 3367, 3253, 1696, 1602, 1455, 1436, 1419, 1323, 1253, $1208,1155,985$. UV/Vis $\left(\lambda_{\max }, \mathrm{nm}, \varepsilon, \mathrm{cm}^{-1} \mathrm{M}^{-1}\right): 242(40,400), 278(23,100), 300(26,700) .{ }^{1} \mathrm{H}$ NMR $\left(300 \mathrm{MHz}, d_{6}\right.$-DMSO): $\delta_{H} 3.59$ (6H, s, OMe), 3.84, 3.65 and 3.76 (each $3 \mathrm{H}, \mathrm{s}, \mathrm{OMe}), 6.09$ (1H, s, H4"), 6.37 (2H, s, H2" and H6"), 6.50 and 6.73 (each $1 \mathrm{H}, \mathrm{s}, \mathrm{H} 3$ and $\mathrm{H} 6$ ), $7.25(2 \mathrm{H}, \mathrm{m}$, aryl H5' and H6'), 7.46 and 8.19 (each $1 \mathrm{H}, \mathrm{d}, \mathrm{J} 4.9 \mathrm{~Hz}$, aryl H4' and H7'), $10.03\left(1 \mathrm{H}\right.$, br s, CONH), 11.67 and 12.19 (each $1 \mathrm{H}$, br s, NH and $\mathrm{NH}^{\prime}$ ); signals at 10.03, 11.67 and $12.19 \mathrm{ppm}$ exchanged with $\mathrm{D}_{2} \mathrm{O} .{ }^{13} \mathrm{C}$ NMR (75 MHz, $d_{6}$-DMSO): $\delta_{c}$ 51.9, 55.2, 55.9, 56.9 (OMe), 93.8, 95.8, 98.1, 107.8, 112.2, 121.2, 122.4, 123.2 (aryl CH), 103.2, 111.0, 123.8, 127.7, 128.5, 128.6, 136.5, 140.1, 144.0, 148.6, 153.1, 160.3 (aryl C), 161.6 (들 $\mathrm{Me}), 164.7$ (CONH), 186.7 (CO). MS (+EI, m/z, \%): 558 (4), 557 (M, 14$), 391$ (14), 378 (15), 377 (100), 350 (20), 345 (19), 318 (33), 303 (38), 203 (16), 180 (14), 137 (36), 125 (39), 122 (24). Anal. calcd for $\mathrm{C}_{30} \mathrm{H}_{27} \mathrm{~N}_{3} \mathrm{O}_{8} .0 .5 \mathrm{H}_{2} \mathrm{O}: \mathrm{C}, 63.60 ; \mathrm{H}, 4.98 ; \mathrm{N}, 7.42$. Found: $\mathrm{C}, 63.55 ; \mathrm{H}, 4.97 ; \mathrm{N}, 7.09 \%$.

4-(Indol-2'-yl)-5,7-dimethoxyindole-2-carboxylate (15). The biindolyl-2-carboxylate 9 (0.20 g, $0.57 \mathrm{mmol})$ was heated at reflux in aqueous ethanolic $(1: 1 \mathrm{v} / \mathrm{v})$ potassium hydroxide $(0.5 \mathrm{M}, 10 \mathrm{~mL})$ for $30 \mathrm{~min}$. After cooling, the solution was poured onto crushed ice and acidified with excess glacial acetic acid. The resulting precipitate was filtered through a frit, washed with water, and dried to give the title compound $(0.192 \mathrm{~g}, 100 \%)$ as a yellow powder, $\mathrm{mp} 250{ }^{\circ} \mathrm{C}$ (dec.); $R_{f}=0.1\left(5 \% \mathrm{MeOH} / \mathrm{CH}_{2} \mathrm{Cl}_{2}\right)$. IR $\left(v_{\max }, \mathrm{cm}^{-1}\right)$ : 3436, 1692, 1315, $1258,1211$. UV/Vis $\left(\lambda_{\max }, \mathrm{nm}, \varepsilon, \mathrm{cm}^{-1} \mathrm{M}^{-1}\right): 246(27,000), 281$ (14,000), $291(16,000), 314(17,000), 360$ (12,000). ${ }^{1} \mathrm{H}$ NMR (300 MHz, $d_{6}$-DMSO): $\delta_{H} 3.86$ and 3.99 (each 3H, s, OMe), $6.66\left(1 \mathrm{H}, \mathrm{d}, J 1.1 \mathrm{~Hz}, \mathrm{H} 3^{\prime}\right), 6.79(1 \mathrm{H}, \mathrm{s}, \mathrm{H} 6), 6.96$ and 7.04 (each $1 \mathrm{H}, \mathrm{t}, J$ 6.8, $7.2 \mathrm{~Hz}, \mathrm{H} 5^{\prime}$ and $\mathrm{H}^{\prime}$ ), $7.23\left(1 \mathrm{H}, \mathrm{d}, J 1.9 \mathrm{~Hz}, \mathrm{H} 3\right.$ ), 7.44 and 7.53 (each $1 \mathrm{H}, \mathrm{d}, J 7.5 \mathrm{~Hz}, \mathrm{H} 4^{\prime}$ and $\mathrm{H}^{\prime}$ ), 10.94 and 11.65 (each $1 \mathrm{H}, \mathrm{br}, \mathrm{NH}$ and $\left.\mathrm{NH}^{\prime}\right) .{ }^{13} \mathrm{C} \mathrm{NMR}$ (75 MHz, $d_{6}$-DMSO): $\delta_{\mathrm{c}} 56.1$ and 57.8 (OMe), 95.2 (C6), 101.4, 108.2, 111.6, 119.1, 119.7, 120.9 (aryl CH), 105.7, 124.4, 127.3, 128.5, 130.1, 134.3, 136.4, 147.2, 151.7 (aryl C), $162.8\left(\underline{C O}_{2} \mathrm{H}\right) . \mathrm{MS}(+\mathrm{El}, \mathrm{m} / \mathrm{z}, \%): 338(3), 337(\mathrm{M}+1,18), 336(\mathrm{M}, 100), 320$ (17), $318(23)$, 303 (58), 276 (50), 275 (28), 203 (15), 159 (21). Anal. calcd for $\mathrm{C}_{19} \mathrm{H}_{16} \mathrm{~N}_{2} \mathrm{O}_{4} .0 .75$ HOAc: C, 64.56; H, 5.02; N, 7.35. Found: $C, 64.31 ; H, 5.16 ; N, 7.43 \%$.

4-(Indol-2'-yl)-5,7-dimethoxyindole (16). A mixture of the indole-2-carboxylate 15 (3.44 g, $10.2 \mathrm{mmol})$ in freshly distilled quinoline $(50 \mathrm{~mL})$ was heated at reflux with copper powder $(0.65 \mathrm{~g}, 10.3 \mathrm{mmol})$ for $105 \mathrm{~min}$ under nitrogen. The resulting black mixture was allowed to cool to room temperature before it was filtered and the filtrate poured over crushed ice. The resulting mixture was acidified to $\mathrm{pH}$ 3-4 using concentrated hydrochloric acid and extracted with ethyl acetate. The organic extract was washed sequentially with $1 \mathrm{M}$ hydrochloric acid several times, saturated aqueous sodium bicarbonate solution several times, and finally twice with brine. The solution was then dried $\left(\mathrm{MgSO}_{4}\right)$, the solvent evaporated in vacuo, and the remaining dark residue was purified via column chromatography $\left(\mathrm{CH}_{2} \mathrm{Cl}_{2}\right)$ to give the title compound $(2.10 \mathrm{~g}, 70 \%)$ as a cream coloured powder, $\mathrm{mp} 162-165^{\circ} \mathrm{C}(\mathrm{AmOH}) ; R_{f}=0.8\left(1 \% \mathrm{MeOH} / \mathrm{CH}_{2} \mathrm{Cl}_{2}\right)$. IR $\left(v_{\max }, \mathrm{cm}^{-1}\right): 3440,1584,1456$, 1312. UV/Vis $\left.\left(\lambda_{\max }, \mathrm{nm}, \varepsilon, \mathrm{cm}^{-1} \mathrm{M}^{-1}\right): 24020,800\right), 266(7,600), 333(23,700) .{ }^{1} \mathrm{H}$ NMR $\left(300 \mathrm{MHz}, \mathrm{CDCl}_{3}\right): \delta_{H} 3.91$ and 4.01 (each $3 \mathrm{H}, \mathrm{s}, \mathrm{OMe}), 6.54(1 \mathrm{H}, \mathrm{s}, \mathrm{H} 6), 6.98(1 \mathrm{H}, \mathrm{d}, J 2.3 \mathrm{~Hz}, \mathrm{H} 2), 6.99\left(1 \mathrm{H}, \mathrm{br} \mathrm{s}, \mathrm{H} 3 \mathbf{\prime}^{\prime}\right), 7.09-7.21(2 \mathrm{H}, \mathrm{m}$, H5' and H6'), $7.25(1 \mathrm{H}, \mathrm{d}, J 1.9 \mathrm{~Hz}, \mathrm{H} 3), 7.43\left(1 \mathrm{H}, \mathrm{d}, J 7.9 \mathrm{~Hz}, \mathrm{H} 7^{\prime}\right), 7.67\left(1 \mathrm{H}, \mathrm{d}, J 7.5 \mathrm{~Hz}, \mathrm{H} 4{ }^{\prime}\right), 8.40(1 \mathrm{H}, \mathrm{br} \mathrm{s}, \mathrm{NH})$, 
$9.47\left(1 \mathrm{H}, \mathrm{br} \mathrm{s}, \mathrm{NH}^{\prime}\right) .{ }^{13} \mathrm{C} \mathrm{NMR}\left(75 \mathrm{MHz}, \mathrm{CDCl}_{3}\right): \delta_{\mathrm{c}} 56.0$ and 59.1 (OMe), 93.3 (C6), 102.0, 104.0, 111.0, 119.8, 120.4, 121.7, 125.4 (aryl CH), 106.6, 123.3, 127.8, 129.1, 135.5, 136.1, 146.4, 152.0 (aryl C). MS (+El, m/z, \%): 294 (3), 293 (M+1, 18), 292 (M, 100), 277 (69), 249 (20), 234 (24), 205 (15), 146 (28), 125 (17), 117 (20). Anal. calcd for $\mathrm{C}_{18} \mathrm{H}_{16} \mathrm{~N}_{2} \mathrm{O}_{2}:$ C, 73.96; $\mathrm{H}, 5.52 ; \mathrm{N}, 9.58$. Found: $\mathrm{C}, 73.73 ; \mathrm{H}, 5.60 ; \mathrm{N}, 9.71 \%$.

4-(Indol-2'-yl)-5,7-dimethoxyindole-3'-carbaldehyde (17). Dimethylformamide (1.0 mL) was cooled in a saltice slurry and treated with phosphoryl chloride $(0.10 \mathrm{~mL}, 1.1 \mathrm{mmol})$ and the mixture stirred for $15 \mathrm{~min}$. This solution was then added dropwise, over $10 \mathrm{~min}$, to a similarly cooled and stirred solution of the indole 16 $(0.15 \mathrm{~g}, 0.51 \mathrm{mmol})$ in dimethylformamide $(2.0 \mathrm{~mL})$. The resulting solution was stirred further with cooling for $25 \mathrm{~min}$ before chilled water was added and the mixture basified to high $\mathrm{pH}$ with $5 \mathrm{M}$ sodium hydroxide solution. The mixture was then stirred with cooling for $15 \mathrm{~min}$ before the resulting precipitate was filtered, washed with water, dried, and purified via chromatography $\left(1 \% \mathrm{MeOH} / \mathrm{CH}_{2} \mathrm{Cl}_{2}\right)$ to give the title compound $(0.20 \mathrm{~g}, 91 \%)$ as a yellow powder, $\mathrm{mp} 221-223{ }^{\circ} \mathrm{C}\left(\mathrm{AmOH} /\right.$ EtOAc/light petroleum). IR $\left(\mathrm{v}_{\max }, \mathrm{cm}^{-1}\right): 3368,3260$, $1609,1579,1456,1366,1314,1241,1200,1112,1064$. UV/Vis $\left(\lambda_{\max }, \mathrm{nm}, \varepsilon, \mathrm{cm}^{-1} \mathrm{M}^{-1}\right): 248(22,000), 269$ (18,000), 282 (14,000), 295 (14,000), 336 (11,000). ${ }^{1} \mathrm{H}$ NMR (300 MHz, d 6 -DMSO): $\delta_{H} 3.78$ and 4.03 (each 3H, s, OMe), $6.16(1 \mathrm{H}, \mathrm{t}, J$ 2.3, $2.3 \mathrm{~Hz}, \mathrm{H} 3), 6.71(1 \mathrm{H}, \mathrm{s}, \mathrm{H} 6), 7.21\left(2 \mathrm{H}, \mathrm{m}, \mathrm{H} 5^{\prime}\right.$ and H6'), $7.28(1 \mathrm{H}, \mathrm{t}, J 3.0,2.6 \mathrm{~Hz}, \mathrm{H} 2)$, 7.45 and 8.14 (each $1 \mathrm{H}, \mathrm{m}, \mathrm{H} 4^{\prime}$ and $\mathrm{H}^{\prime}$ ), $9.65(1 \mathrm{H}, \mathrm{s}, \mathrm{CHO}), 11.31$ and 11.99 (each $1 \mathrm{H}, \mathrm{br} \mathrm{s}, \mathrm{NH}$ and $\left.\mathrm{NH}^{\prime}\right) .{ }^{13} \mathrm{C}$ NMR (75 MHz, $d_{6}$-DMSO): $\delta_{c} 56.0$ and 57.6 (OMe), 91.5 (C6), 100.9, 112.1, 121.0, 122.2, 123.2, 127.2 (aryl CH), 101.2, 114.1, 121.7, 125.7, 130.0, 136.7, 146.7, 148.2, 152.7 (aryl C), 186.2 (CHO). MS (+El, $\mathrm{m} / \mathrm{z}, \%): 321$ (5), 320 (M, 24), 290 (22), 289 (100), 274 (19), 205 (21), 123 (20), 109 (27). Anal. calcd for $\mathrm{C}_{19} \mathrm{H}_{16} \mathrm{~N}_{2} \mathrm{O}_{3}: \mathrm{C}, 71.24 ; \mathrm{H}$, $5.03 ; \mathrm{N}, 8.74$. Found: C, 71.50; $\mathrm{H}, 5.14 ; \mathrm{N}, 8.94 \%$.

4-(Indol-2'-yl)-5,7-dimethoxyindole-3,3'-dicarbaldehyde (18). Dimethylformamide (1.0 mL) was cooled in a salt-ice slurry and treated with phosphoryl chloride $(0.53 \mathrm{~mL}, 5.7 \mathrm{mmol})$ and the mixture stirred for $15 \mathrm{~min}$. This solution was then added dropwise, over $4 \mathrm{~min}$, to a similarly cooled and stirred solution of the indole 16 $(0.10 \mathrm{~g}, 0.34 \mathrm{mmol})$ in dimethylformamide $(1.0 \mathrm{~mL})$. The solution was stirred further with cooling for $30 \mathrm{~min}$, then for $2.5 \mathrm{~h}$ at ambient temperature before the mixture was again cooled and treated with chilled water and basified to high $\mathrm{pH}$ with $5 \mathrm{M}$ sodium hydroxide solution. The mixture was stirred with cooling for 15 min and then extracted with ethyl acetate. The organic extract was washed with brine, dried $\left(\mathrm{MgSO}_{4}\right)$, and the solvent evaporated in vacuo to give the title compound $(0.07 \mathrm{~g}, 59 \%)$ as a pale yellow powder, $\mathrm{mp}>200{ }^{\circ} \mathrm{C}$ (dec.), which could not be obtained analytically pure. IR $\left(v_{\max }, \mathrm{cm}^{-1}\right): 3238,1674,1611,1583,1455,1379,1341,1208$. UV/Vis $\left(\lambda_{\max }, \mathrm{nm}, \varepsilon, \mathrm{cm}^{-1} \mathrm{M}^{-1}\right): 244$ (25,000), 257 (25,000), $300(17,000), 390(3,200) .{ }^{1} \mathrm{H} \mathrm{NMR}\left(300 \mathrm{MHz}, d_{6^{-}}\right.$ DMSO): $\delta_{H} 3.78$ and 4.06 (each $\left.3 \mathrm{H}, \mathrm{s}, \mathrm{OMe}\right), 6.84(1 \mathrm{H}, \mathrm{s}, \mathrm{H} 6), 7.23\left(2 \mathrm{H}, \mathrm{m}, \mathrm{H} 5^{\prime}\right.$ and H6'), $7.42\left(1 \mathrm{H}, \mathrm{m}, \mathrm{H} 4^{\prime}\right), 8.03$ $(1 \mathrm{H}, \mathrm{d}, J 2.6 \mathrm{~Hz}, \mathrm{H} 2), 8.11\left(1 \mathrm{H}, \mathrm{m}, \mathrm{H}^{\prime}\right.$ ) , 8.91 and 9.49 (each $\left.1 \mathrm{H}, \mathrm{s}, \mathrm{CHO}\right), 12.15$ and 12.53 (each $1 \mathrm{H}, \mathrm{br} \mathrm{s}, \mathrm{NH}$ and $\left.\mathrm{NH}^{\prime}\right) .{ }^{13} \mathrm{C}$ NMR (75 MHz, $d_{6}$-DMSO): $\delta_{c} 56.4$ and 57.5 (OMe), 92.6 (C6), 112.3, 121.0, 122.3, 123.4, 134.6 (aryl $\mathrm{CH}), 101.2,115.5,118.5,122.4,125.5,127.5,136.6,147.2,148.7,155.4$ (aryl C), 183.8 and 185.4 (CHO).

1,1'-Di-(tert-butyloxycarbonyl)-4-(indol-2'-yl)-5,7-dimethoxyindole-3,3'-dicarbaldehyde (19). A suspension of the indole-3,3'-dicarbaldehyde $18(0.10 \mathrm{~g}, 0.28 \mathrm{mmol})$, di-tert-butyldicarbonate $(0.24 \mathrm{~g}, 1.10 \mathrm{mmol})$ and $\mathrm{N}, \mathrm{N}$ dimethylaminopyridine $(10 \mathrm{mg})$ in anhydrous acetonitrile $(5.0 \mathrm{~mL})$ was stirred at $40{ }^{\circ} \mathrm{C}$ for 1 day. The solvent was then evaporated in vacuo and the remaining residue purified via column chromatography $\left.\left(\mathrm{CH}_{2} \mathrm{Cl}_{2}\right)\right)$ to give the title compound $(0.70 \mathrm{~g}, 45 \%)$ as a bright yellow syrup that solidified upon standing, $\mathrm{mp} 80-88{ }^{\circ} \mathrm{C}$ (softens), $95{ }^{\circ} \mathrm{C}$ (dec.); $R_{f}=0.7\left(2.5 \% \mathrm{MeOH} / \mathrm{CH}_{2} \mathrm{Cl}_{2}\right)$. IR $\left(v_{\max }, \mathrm{cm}^{-1}\right): 1747,1737,1688,1668,1606,1455,1368,1340$, 1323, 1251, 1213, 1154, 1142. UV/Vis $\left(\lambda_{\max }, \mathrm{nm}, \varepsilon, \mathrm{cm}^{-1} \mathrm{M}^{-1}\right): 242(28,600), 298(16,000), 319(11,100) .{ }^{1} \mathrm{H} N M R$ $\left(300 \mathrm{MHz}, \mathrm{CDCl}_{3}\right.$ ): $\delta_{H} 1.18$ and 1.66 (each $9 \mathrm{H}, \mathrm{s}, \mathrm{CMe}_{3}$ ), 3.79 and 4.04 (each $\left.3 \mathrm{H}, \mathrm{s}, \mathrm{OMe}\right), 6.64$ (1H, s, H6), 7.40 $\left(2 \mathrm{H}, \mathrm{m}, \mathrm{H} 5^{\prime}\right.$ and $\left.\mathrm{H}^{\prime}\right), 8.17(1 \mathrm{H}, \mathrm{s}, \mathrm{H} 2), 8.26$ and 8.35 (each $1 \mathrm{H}, \mathrm{d}, \mathrm{J} 7.5 \mathrm{~Hz}, \mathrm{H} 4^{\prime}$ and $\mathrm{H}^{\prime}$ ), 9.29 and 9.52 (each $1 \mathrm{H}$, s, CHO). ${ }^{13} \mathrm{C} \mathrm{NMR}\left(75 \mathrm{MHz}, \mathrm{CDCl}_{3}\right): \delta_{\mathrm{C}} 27.4$ and 27.7 ( $\mathrm{CMe}_{3}$ ), 56.1 and 56.6 (OMe), 83.9 and $85.4(\underline{\mathrm{CMe}}), 93.7$ 
(C6), 115.3, 121.7, 124.4, 125.5, 137.6 (aryl CH), 103.8, 120.1, 120.4, 120.8, 125.6, 130.0, 136.6, 145.4, 148.0, 149.2, 149.7, 156.1 (CO and aryl C), 184.1 and 187.6 (CHO). MS (+EI, $m / z, \%): 549$ (4), 548 (M, 10), 331 (31), 319 (26), 318 (16), 317 (100), 304 (17), 303 (30), 289 (17). Anal. calcd for $\mathrm{C}_{30} \mathrm{H}_{32} \mathrm{~N}_{2} \mathrm{O}_{8} . \mathrm{H}_{2} \mathrm{O}: \mathrm{C}, 63.59 ; \mathrm{H}, 6.05 ; \mathrm{N}$, 4.94. Found: C, 63.69; $H, 5.80 ; N, 4.75 \%$.

\section{Acknowledgements}

Financial support from the Australian Research Council is gratefully acknowledged (DP180100845).

\section{References}

1. Itoh, S.; Takada, N.; Ando, T.; Haranou, S.; Huang, X.; Uenoyama, Y.; Ohshiro, Y.; Komatsu, M.; Fakuzumi, S. J. Org. Chem. 1997, 62, 5898-5907.

https://doi.org/10.1021/jo970716l

2. Itoh, S.; Ohshiro, Y. Nat. Prod. Rep. 1995, 12, 45-53. https://doi.org/10.1039/np9951200045

3. Davidson, V. L. Adv. Exp. Med. Biol. 1999, 467, 587-595. https://doi.org/10.1007/978-1-4615-4709-9 73

4. Murase, M.; Watanabe, K.; Yoshida, T.; Tobinaga, S. Chem. Pharm. Bull. 2000, 48, 81-84. https://doi.org/10.1248/cpb.48.81

5. Murase, M.; Watanabe, K.; Kurihara, T.; Tobinaga, S. Chem. Pharm. Bull. 1998, 46, 889-892. https://doi.org/10.1248/cpb.46.889

6. Brenner, M.; Mayer, G.; Terpin, A.; Steglich, W. Chem. Eur. J. 1997, 3, 70-74. https://doi.org/10.1002/chem.19970030112

7. Itoh, S.; Ogino, M.; Komatsu, M.; Ohshiro, Y. J. Am. Chem. Soc. 1992, 114, 7294-7295. https://doi.org/10.1021/ja00044a050

8. Napolitano, A.; Corradini, M. G.; Prota, G. Tetrahedron 1987, 43, 2749-2754. https://doi.org/10.1016/S0040-4020(01)86880-0

9. D'Ischia, M.; Prota, G. Tetrahedron 1987, 43, 431-434. https://doi.org/10.1002/1097-4679(198705)43:3<431::AID-JCLP2270430318>3.0.CO;2-1

10. Corradini, M. G.; Napolitano, A.; Prota, G. Tetrahedron 1986, 42, 2083-2088. https://doi.org/10.1016/S0040-4020(01)87625-0

11. Wrona, M. Z.; Dryhurst, G. J. Org. Chem. 1989, 54, 2718-2721. https://doi.org/10.1021/j000272a048

12. Goyal, R. N.; Garg, D. K. Bioelectrochem. Bioenerg. 1996, 39, 249-257. https://doi.org/10.1016/0302-4598(95)01881-6

13. Napolitano, A.; Pezzella, A.; D'Ischia, M.; Prota, G. Tetrahedron 1996, 52, 8775-8780. https://doi.org/10.1016/0040-4020(96)00418-8

14. Condie, G. C.; Channon, M. F.; Ivory, A. J.; Kumar, N.; Black, D. StC. Tetrahedron 2005, 61, 4989-5004. https://doi.org/10.1016/j.tet.2005.03.048 
15. Condie, G. C.; Channon, M. F.; Craig, D. C.; Bhadbhade, M.; Kumar, N.; Black, D. StC. Arkivoc 2020, 117144.

https://doi.org/10.24820/ark.5550190.p011.252

16. Black, D. StC.; Bowyer, M. C.; Ivory, A. J.; Jolliffe, K. A.; Kumar, N. Tetrahedron 1996, 52, 4687-4696. https://doi.org/10.1016/0040-4020(96)00140-8

17. Black, D. StC.; Bowyer, M. C.; Kumar, N. Tetrahedron 1997, 53, 8573-8584. https://doi.org/10.1016/S0040-4020(97)00516-4

18. Bergman, J.; Eklund, N. Tetrahedron 1980, 36, 1445-1450. https://doi.org/10.1016/0040-4020(80)85060-5

19. Black, D. StC.; Ivory, A. J.; Kumar, N. Tetrahedron 1996, 52, 4697-4708. https://doi.org/10.1016/0040-4020(96)00141-X

20. Black, D. StC.; Ivory, A. J.; Kumar, N. Tetrahedron 1996, 52, 7003-7012. https://doi.org/10.1016/0040-4020(96)00305-5

21. Ciamician, G. L.; Silber, P. Ber. Dtsch. Chem. Ges. 1884, 17, 553-559. https://doi.org/10.1002/cber.188401701154 